\title{
Recognizing the Importance of Brand Awareness on E-commerce Sales while Shopping on Internet: Empirical Analysis of European Countries
}

\author{
http://dx.doi.org/10.3991/ijim.v9i1.4111 \\ Bader M. Al-Fawwaz, Atallah M. Al-Shatnawi and Wafa S. AlSharafat \\ Al al-Bayt University, Jordan
}

\begin{abstract}
The reason to conduct this research is to investigate and recognize the importance of brand awareness on $E$ commerce sales while shopping on Internet. Empirical analysis of seven top Internet purchasing European countries is done by using the report of (Eurostat's 2011). The units of analysis are those individuals who are residing in Denmark, Germany, France, Italy, Netherland, Sweden and Norway making purchases from the Internet. Data is collected from the report of Eurostat's for the ten years from 2002-2011. To find out the relationship between Independent and Dependent Variable in the online business world, the study has done statistical analyses which are implemented by using $\mathbf{E}$ views 5 software. The main motive to carry out the study is to find out the impact and importance of brand image/ awareness in the minds of online shopper, when they go for shopping on Internet. Findings of this study illustrate significant positive relationship between brand awareness an $\mathrm{E}$ commerce sale. Findings are beneficial for those companies which are working on Internet and selling their products or services, so with the help of results of this study they can be able to know European online shopper's mind and can develop certain strategies in order to sell the most.
\end{abstract}

Index Terms-Brand awareness, E-commerce, Europe Internet shopping, E-business.

\section{INTRODUCTION}

Internet is a novel way to shop products and services online. There are plenty of web stores available online through which customers can conveniently make purchases. Nielsen (2012) stated that spending on Internet is increasing in the entire European countries. Furthermore, the Internet advertisement spending is on its growth and particularly the growth in Internet advertisement is observed as $12.1 \%$ in Europe. Overall the trends in online shopping are not only increasing but people are more tend to trust on Internet e-commerce sites and make purchases. If in the case someone is looking to buy air tickets he/she can simply log on to the airline websites and purchase the E-tickets. Further, if that consumer is looking for some accommodation in any part of the world, that consumer can simply make purchase by going on the web and surfing different hotel rooms. Shopping was never as easy as this is in today's world (Harfoushi et. al 2013).

There are some other modes of communication such as telephone. However, Internet is such a way of communication which is very convenient to use and a cheap way to communicate in any part of the world. Furthermore, the Internet provides a platform to users where they can interact with the dealers which are sitting in other parts of the world and make purchases. Internet shopping is becoming same like traditional shopping, if you cannot touch the product, however you have complete details given with all the specification of the product, you can simply navigate with that specs of the product and make purchase accordingly. As Internet is an easy platform for every user to access, therefore number of whole sellers, dealers and retailors are now communicating on Internet platform, having business on Internet and make business contracts which are totally based on Internet medium.

Although the Internet market in Europe is under developing stage; most of the people avoids shopping from an E-store. Internet users predict many forms of Internet advertisement which includes the commercial advertisement and electronic advertisement (Ann, 1999). The numbers of Internet users in Europe are recorded 545,057,209 (Internet world stats, 2014). If we see the figure of Internet users we can see it is growing in European countries. Although number of shoppers in Europe is not very much, however this trend is increasing day by day. $60 \%$ of the people who use Internet in Europe have never shopped over Internet (Nielsen, 2012). The progression of the World Wide Web (WWW) and Internet have caused the formation of novel system in trade dealings- electronic transaction or shopping on web (Ling, 2010).

In European countries the number of merchants or firm creating opportunities over Internet is increasing. As use of online banking, E-ticketing, booking of rooms in restaurants and hotels, digital products and purchase of vehicles are on boom nowadays. People like to browse for different services and products through Internet in Europe. That is why it is becoming an essential strategy for any business or firm to create a homepage and promotes it over Internet. As buying a car is just on your click that is why people prefer to use this technology rather than going on a different showrooms and search for a desired car.

The primary focus to conduct this study is to identify and check brand awareness of web consumers in European countries. The primary focus of the study is to analyze the impact of brand awareness toward E-commerce sales in Europe. By studying consumer reactions or attitudes towards shopping over Internet it is easy to find out those factors which are deteriorating the rate of shopping over Internet in the European context. Although consumer attitudes or behavior varies from person to person, however by the support of literature we can find out this phenomena. This paper will be helpful for those businesses and organizations who want to market their products over Internet in the area of Europe. The merchants who want to increase their sales over Internet. As by studying the reac- 
tions of consumers over Internet, it will be helpful for merchants, organizations, sellers in Europe to find out such factors which can enhance and boost up their sales by fulfilling the need of online consumers in Europe.

\section{LITERATURE REVIEW}

The Internet has provided business of all size, with opportunities to expand their market in order to sell the products. Like traditional market, it is a market which allows seller to sell the products online. Internet has shaped an advanced method in which users connect and intermingle. Sellers have a great deal to advantage by using and attaching the control of social networking to improve their global promotion plan (Pookulangara, 2011). Progressively customers are using Internet as a prepurchase instrument where they can interact with other users, can read the reviews and get the information about particular products and services (Adjei, 2010). Internet marketing is entirely different from the traditional marketing. In traditional marketing you have to go to the specific store, outlet in order to purchase a specific item. However, shopping over Internet is entirely different, what you have to do is just visit any E-store, Online Store, E-Shop, or Online Shop and there you can find out your product what you are looking for. E-commerce delivers a detailed description of what E-commerce is, how it's being showed and achieved, and how to measure its main chances, boundaries, matters, and jeopardies all in the computing commercial setting (Turban, 2009). These new selling techniques and changes give a new paradigm for sellers, merchants, organizations, firms to sell their products in a different field with targeted users. By creating the web pages of their respective organizations it leads them to get in touch with the targeted clients or consumers.

\section{A. Consumer Behavior while Shopping on Internet}

Number of studies has been found which have done research on this topic. Several studies (Trusov, 2009), (Dutton, 2011), (Casey, 2011) and (Michel, 2011) all have conducted empirical research about consumer behavior online. The purpose of these researches is to find out the difference between online and offline shopping and marketing concepts. Majority of the above studies is conducted on the price and brand choice of different consumers which are making online purchases, and it was found that mix of price and brand information is also involved when a customer is making purchase on the Internet. Trusov (2009) study finds that although the loyalty of a customer with brand is a strong phenomenon observed in the traditional marketing concept, however this phenomenon is less when consumer is making purchases virtually. Yet most of the customer is always looking for trustable brands when about to shop online and it ease their nerves regarding the quality of the product and they can simply trust on that brand.

Interpersonal trust and economic conditions are some important variable which affects the consumer behavior to shop from an Internet store. Internet shopping not only involves with a person to merchant trust, but it also involves the trust between person to computer system through which safe and sound transactions would be take place (Turban, 2009). A study shows empirically that "on line shopping behavior is indeed affected by interpersonal trust and the economic condition of the on-line shopper. These variables independently affect the styles or behavior of an online shopper who is shopping on World Wide Web. Checking consumer behavior while shopping on Internet has its own significance. As by checking consumer behavior while shopping on Internet, companies and sellers who are working online can increase their sales and operations. With reliable information about the consumer behavior while shopping products or use services online they would be able to design better promotions and programs which would be keyed to motivate consumers for shopping online.

\section{B. Role of Brand Awareness}

The rapid increase in E-commerce provides new challenge for marketers, as online consumer adopts new technologies; their attitude is changing (Dutton, 2011). This study will describe brand awareness in the framework of online shopping. There are certain differences while shopping in traditional market and in online market. Ecommerce normally absences human friendliness and friendliness, meanwhile it is more objective, unidentified and automatic than old-style face-to-face business (Hassanein, 2007).

By brand loyalty it means that consumer is familiar with brand and they preferred that particular brand while shopping products or use services on Internet. Exactly like in traditional market brand awareness put impact on buying behavior of consumers, and consumers become loyal to that particular brand. Same in the case here, brand awareness put positive impact on buying behavior of consumers on Internet. People become loyal to that specific brand from which they are familiar with. A result of studies shows that shopper believes in a web store was a noteworthy forecaster apparent web sureness exploration meaning for product material via the online store (Hahn, 2009). Results of another research finds that the occurrence nonappearance of product's name disturbs web consumers' supposed threat, but in the contradictory way to that predictable (Huang, 2004). These all findings and studies show that brand awareness has a significant role while purchasing products and use services on Internet.

\section{Problem Statement}

By reviewing the literature it has been found that there are several studies which have for checking the consumer awareness only with brand awareness. There are very few studies which are conducted in the context of Europe. Furthermore, the two variables brand awareness among consumers and E-commerce sale; very few have used them as a variable in the studies. Although, some has studies these variables as independent variables which put ultimate effect of consumer behavior, but very few has studies them by taking as an independent and dependent variables. So the gap lies here that very few studies have conducted in European context.

\section{RESEARCH QUESTION}

To what extent brand awareness put impact on ecommerce sales while a consumer shops through Internet in Europe?

\section{THEORETICAL FrameWORK}

The Theoretical Framework of "Recognizing the Importance of Brand Awareness on E-commerce Sales while Shopping on Internet: Empirical Analysis of European Countries". 
Independent Variables

Dependent Variables

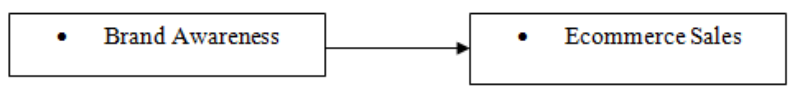

\section{RESEARCH Methodology}

This section discusses the research methodology which is utilized to find out the relationship between independent variables and dependent variables. The methodology of this paper is quantitative and based on primary as well as secondary data collection. Secondary data is collected from 07 countries which are located under the territory of Europe. The names of countries are Denmark, Germany, France, Italy, Netherland, Sweden and Norway. Sample size is 77 . The data is collected from those countries which are on top of spending and making online purchases on Internet. The data for independent variables which is brand awareness is collected from the consumers through online survey by sending them questionnaire. For dependent variable, the data set is collected from the reports of (Eurostats, 2011). Also Emails were sent to consumers in Europe in order to collect the data of brand awareness and to collect the right data. When contacted to Gallup it was found even they did not collected this information so this research was carried out by personal effect. Total 77 observations have been recorded of the independent variable. The research paradigm for conducting this research is deductive and approach is positivist. Questionnaire was distributed among 82 respondents out of which 77 were received back. So response rate is $94 \%$ which is enough to carry on the research.

Data was first recorded in Microsoft Excel, and then it was exported to E-views 5. After exporting to E-views 5, regression is run by using dependent variable which is Ecommerce sales and independent variable is brand awareness. Different results which include descriptive statistics such as mean, median and kurtosis are received which all are in good order. Further regression results also achieved which are also in good order and results showing significant relationship. Moreover; the correlation matrix is generated which also showing strong positive relationship between the independent and dependent variable.

\section{RESULTS \& DISCUSSIONS}

In the following section the results are given which received from E-views. Firstly in this section descriptive statistics detail is given, which include mean, median, standard deviation, skewness and kurtosis. Secondly further the results of regression and correlation are analyzed.

In Table I, descriptive statistics is mentioned as per independent and dependent variable. The total numbers of observations are 77 which are from 07 countries of Europe, and data is collected for ten years from 2002-2011. The Sample of the paper discloses that mean of brand awareness is 170.4400; and the mean of dependent variable which is E-commerce Sales is 18.66200. Also the standard deviation (S.D) of classified advertisement is 171.1560; and the standard deviation (S.D) of dependent variable which is E-commerce Sales is 21.02158. In addition to Mean and Standard Deviation if we see the probability results than the probability of brand awareness is 0.002877 and the probability of dependent variable which is e-commerce sales is 0.002598 .
Table II illustrates the Matrix of correlation in which correlation findings of every variable is displayed. As the independent variable is brand awareness, and one dependent variable i.e. E-commerce Sales, all correlations results are mentioned. Correlation is actually defined as the degree of relationship amongst two main variables. Result of correlation amongst the variable itself such as brand awareness is strongly significant or 1 and vice versa. A correlation result amongst brand awareness and Ecommerce sales is 0.79 which displays strong relationship. Similarly, correlation results amongst classified and Ecommerce sales are 0.79 which too displays strong relationship. Similarly correlation result for the dependent variable itself is 1 , and when we see the correlation result between E-commerce sales and brand awareness it is 0.83 which depicts a very strong relationship with each other.

TABLE I.

DESCRIPTIVE STATISTICS

\begin{tabular}{|l|c|c|}
\hline & BRAND AWARENESS & ECOMSALE \\
\hline Mean & 170.4400 & 18.66200 \\
\hline Median & 137.0000 & 17.85000 \\
\hline Maximum & 834.0000 & 89.50000 \\
\hline Minimum & 4.000000 & 0.900000 \\
\hline Std. Dev. & 171.1560 & 21.02158 \\
\hline Skewness & 0.81025 & 1.48963 \\
\hline Kurtosis & 1.983698 & 5.125896 \\
\hline Jarque-Bera & 8.125896 & 24.589652 \\
\hline Probability & 0.002877 & 0.002598 \\
\hline Sum & 13589.00 & 11502.00 \\
\hline Sum Sq. Dev. & 35926.85 & 198523.00 \\
\hline Observations & 77 & 77 \\
\hline
\end{tabular}

TABLE II.

CORRELATION MATRIX

\begin{tabular}{|l|c|c|}
\hline & BRAND AWARENES & ECOMSALE \\
\hline BRAND AWARENES & 1 & 0.798563598756 \\
\hline ECOMSALE & 0.836985623642698 & 1 \\
\hline
\end{tabular}

TABLE III.

ORDINARY LEASE SQUARE REGRESSION STATISTICS

\begin{tabular}{|c|c|c|c|c|}
\hline \multicolumn{5}{|c|}{ Dependent Variable: ECOMSALE } \\
\hline \multicolumn{5}{|c|}{ Method: Panel Least Squares } \\
\hline \multicolumn{5}{|c|}{ Date: $05 / 01 / 14$ Time: $05: 41$} \\
\hline \multicolumn{5}{|l|}{ Sample: 2002- 2011} \\
\hline \multicolumn{5}{|c|}{ Cross-sections included: 7} \\
\hline \multicolumn{5}{|c|}{ Total panel (balanced) observations: 77} \\
\hline Variable & Coefficient & Std. Error & t-Statistic & Prob. \\
\hline $\mathrm{C}$ & 2.987469 & 1.897526 & 3.356987 & 0.0002 \\
\hline $\begin{array}{l}\text { BRAND } \\
\text { AWARENESS }\end{array}$ & 0.159752 & 0.025986 & $3.125986^{*}$ & 0.0015 \\
\hline R-squared & 0.996354 & \multicolumn{2}{|c|}{ Mean dependent var } & 18.69678 \\
\hline $\begin{array}{l}\text { Adjusted R- } \\
\text { squared }\end{array}$ & 0.907526 & \multicolumn{2}{|c|}{ S.D. dependent var } & 17.25698 \\
\hline S.E. of regression & 3.256896 & \multicolumn{2}{|c|}{ Akaike info criterion } & 3.547865 \\
\hline Sum squared resid & 869.36589 & \multicolumn{2}{|c|}{ Schwarz criterion } & 5.002589 \\
\hline Log likelihood & 155.68952 & \multicolumn{2}{|c|}{ F-statistic } & 287.6982 \\
\hline $\begin{array}{l}\text { Durbin-Watson } \\
\text { stat }\end{array}$ & 1.369365 & \multicolumn{2}{|c|}{ Prob(F-statistic) } & 0.000000 \\
\hline
\end{tabular}

Note: Shows significance at $1 \%$ level of significance 
Table III portrays through Ordinary Least Square (OLS) regression. The overall constant value of probability is 0.0002 which shows it has very high or strong important influence of the entire model. Particularly when we see the probability value of brand awareness it is 0.0015 which is also less than the level of significance and it also shows strong positive significant impact on the dependent variable. T-stats also depict the fitness of model and tell the significance of the relationship. As per table (3); the t-stats of brand awareness is 3.12 which is more than 2 so it displays significant positive influence of brand awareness on dependent variable which is E-commerce Sales. The rate of $\mathrm{R}$ square is 0.996 which is more than 0.90 which displays that there is the effect of multicollinearity amongst the independent variables. As we have only one independent variable so we do not need to see the value of R-square because R-square is only seeing when there are two or more than two independent variables.

\section{CONCLUSION}

The primary motive to carry out this study is to investigate and recognizing the importance of brand awareness on E-commerce sales while shopping on Internet. This is basically the empirical analysis of seven top Internet purchasing European countries. From last couple of decades Internet is growing rapidly and today Internet is accessed by plenty of users sitting in their homes around the globe. This revolutionary platform not only eases the communication between the Internet users, but also the e-commerce websites are developed which are attracting consumers to make purchases. This study is targeting seven countries of Europe which are on the top of online purchases as compared to other European countries. These countries are Denmark, Germany, France, Italy, Netherlands, Sweden and Norway. Data is collected for ten years 2002-2011 from the report of (Eurostats, 2011). The independent variable of this study is brand awareness, for which data is collected through a questionnaire. Results indicates that brand awareness is positively associated with the online purchases and further with the E-commerce sales, Further regression results depicts strong significance between both explanatory and dependent variable, It displays that there is a strong positive significant relationship amongst brand awareness and dependent variable which is online shopping. Findings indicate that companies should work on Internet with proper brand names, and they should implement such strategies through which they can enhance the credibility of their brands. Also companies which are performing Internet business activity they need to create awareness of their brands in the minds of customers, so that more customers attracts towards their products or services and in this way they can have more e-commerce sales.

\section{REFERENCES}

[1] Adjei, M. T., Noble, S. M., \& Noble, C. H. (2010). The influence of $\mathrm{C} 2 \mathrm{C}$ communications in online brand communities on customer purchase behavior. Journal of the Academy of Marketing Science, 38(5), 634-653. http://dx.doi.org/10.1007/s11747-009-0178-5

[2] Ann E Schlosser, S. S. (1999). Survey of Internet users: Attitude towards Internet advertisement. Journal of Interactive Marketing, 13.
[3] Casey, E. (2011). Digital evidence and computer crime: forensic science, computers and the Internet. Academic press.

[4] Dutton, W. H., \& Blank, G. (2011). Next generation users: The Internet in Britain.

[5] Eurostats. (2011). Online ad spend across Europe. France: http://www.ec.europa.eu/eurostat/.

[6] Hahn, K. H., \& Kim, J. (2009). The effect of offline brand trust and perceived Internet confidence on online shopping intention in the integrated multi-channel context. International Journal of Retail \& Distribution Management, 37(2), 126-141. http://dx.doi.org/10.1108/09590550910934272

[7] Harfoushi, O; AlFawwaz, B; Obeidat, B; Obiedat, R and Faris, H. "Impact of Internet Advertisement and its Features on ECommerce Retail Sales: Evidence from Europe", Journal of Software Engineering \& Applications, 2013

[8] Hassanein, K., \& Head, M. (2007). Manipulating perceived social presence through the web interface and its impact on attitude towards online shopping. International Journal of Human-Computer Studies, 65(8), 689-708 http://dx.doi.org/10.1016/ j.ijhcs.2006.11.018

[9] Huang, W. Y., Schrank, H., \& Dubinsky, A. J. (2004). Effect of brand name on consumers' risk perceptions of online shopping. Journal of Consumer Behavior, 4(1), 40-50. http://dx.doi.org/10.1002/cb.156

[10] Internet World Stats, I. w. (2013, December 31). Internet world stats. Retrieved 06 19, 2014, from Internet world stats: http://www.Internetworldstats.com.

[11] Ling, K. C., Chai, L. T., \& Piew, T. H. (2010). The effects of shopping orientations, online trust and prior online purchase experience toward customers' online purchase intention. International Business Research, 3(3), P63. http://dx.doi.org/10.5539/ ibr.v3n3p63

[12] Michel Lombera, I., Chuang, Y. T., Melliar-Smith, P. M., \& Moser, L. E. (2011, June). Trustworthy distribution and retrieval of information over HTTP and the Internet. In INTERNET 2011, The Third International Conference on Evolving Internet (pp. 713).

[13] Nielsen. (2012). An Uncommon sense of the Consumer. Nielsen.

[14] Pookulangara, S., \& Koesler, K. (2011). Cultural influence on consumers' usage of social networks and its' impact on online purchase intentions. Journal of Retailing and Consumer Services, 18(4), 348-354. http://dx.doi.org/10.1016/j.jretconser.2011.03.003

[15] Turban, E., Lee, J. K., King, D., Liang, T. P., \& Turban, D. (2009). Electronic commerce 2010. Prentice Hall Press.

[16] Trusov, M., Bucklin, R. E., \& Pauwels, K. (2009). Effects of word-of-mouth versus traditional marketing: findings from an Internet social networking site. Journal of marketing, 73(5), 90-102. http://dx.doi.org/10.1509/jmkg.73.5.90

\section{AUTHORS}

Bader M. Al-Fawwaz is an Assistant Professor at the Department of Information Systems, Prince Hussein Bin Abdullah College for Information Technology, Al-albayt University (Jordan).

Atallah M. AL-Shatnawi is an Assistant Professor at the Department of Information Systems, Prince Hussein Bin Abdullah College for Information Technology, Alalbayt University (Jordan).

Wafa S. Alsharafat is an Assistant Professor at the Department of Information Systems, Prince Hussein Bin Abdullah College for Information Technology, Al-albayt University (Jordan).

Submitted 11 August 2014. Published as resubmitted by the authors on 25 January 2015. 